\title{
Hydrosoluble fiber (Plantago ovata husk) and levodopa I: Experimental study of the pharmacokinetic interaction
}

\author{
Juan J. Garcia, Nelida Fernandez*, Demetrio Carriedo, M. Jose Diez, Ana Sahagun, \\ Aranzazu Gonzalez, Angela Calle, Matilde Sierra \\ Area de Farmacologia, Universidad de Leon, 24071 Leon, Spain
}

Received 21 August 2004; received in revised form 7 January 2005; accepted 11 January 2005

\begin{abstract}
Fiber therapy could be used in patients with Parkinson disease to reduce the symptoms of gastrointestinal disorders; however, it could interact with levodopa reducing its effectiveness. In this experimental study we have investigated whether the presence of Plantago ovata husk (water-soluble fiber) modifies in rabbits the bioavailability and other pharmacokinetic parameters of levodopa (20 mg/kg) when administered by the oral route at the same time. We have also studied whether pharmacokinetic modifications are fiber-dose dependent (100 and $400 \mathrm{mg} / \mathrm{kg}$ ). The extent of levodopa absorbed when administering $100 \mathrm{mg} / \mathrm{kg}$ of fiber (AUC=43.4 $\mu \mathrm{g} \mathrm{min} \mathrm{ml}^{-1}$ ) is approximately the same as when levodopa is administered alone $\left(\mathrm{AUC}=47.1 \mu \mathrm{g} \mathrm{min} \mathrm{ml}^{-1}\right)$; however, $C_{\max }$ is lower $\left(1.04 \mathrm{versus}_{1.43 \mu \mathrm{g} \mathrm{ml}}^{-1}\right)$. Results obtained indicate that fiber at the higher dose increases the extent of levodopa absorbed (AUC $=62.2 \mu \mathrm{g} \mathrm{min} \mathrm{ml}^{-1}$ ), being the value of $C_{\text {max }}$ similar $\left(1.46 \mu \mathrm{g} \mathrm{ml}^{-1}\right)$. The value of $t_{\max }$ increases from $10 \mathrm{~min}$ when levodopa is administered alone to 20 min when the animals receive fiber. On the other hand, since certain time on, levodopa concentrations are always higher in the groups that receive fiber: 60 min with 100 $\mathrm{mg} / \mathrm{kg}$ fiber and $20 \mathrm{~min}$ with $400 \mathrm{mg} / \mathrm{kg}$ fiber. Fiber also increases the mean residence time (MRT). $P$. ovata husk administration with levodopa could be beneficial, not only in patients with constipation, due to: lower adverse reactions (lower values of $C_{\text {max }}$ ) and longer and more stable effects (higher final concentrations and more time in the body).
\end{abstract}

(C) 2005 Elsevier B.V. and ECNP. All rights reserved.

Keywords: Levodopa; Plantago ovata husk; Interaction; Pharmacokinetics; Rabbits; Fiber

\section{Introduction}

Parkinson's disease is a disabling progressive illness affecting about 1 in 1000 individuals mainly over 60 years of age. Diseases that affect the central nervous system can also affect gastrointestinal motility. Patients with Parkinson's disease, in particular, may have numerous motility complications (Garnett, 1996), and as pointed out by Edwards et al. (1992) and Byrne et al. (1994), constipation is a significant problem.

Plantago ovata husk (ispaghula husk, psyllium) is a viscous water-soluble fiber obtained from $P$. ovata (the husk of the seeds of $P$. ovata), that has been used as a bulk laxative with a good safety record for many years. There-

\footnotetext{
* Corresponding author. Tel.: +34 9872915 28; fax: +34 987291252.

E-mail address: dftnfm@unileon.es (N. Fernandez).
}

fore, the employment of this compound would be beneficial in these patients as long as it would not interfere with other drugs administered to treat their illness.

Levodopa is the most effective therapeutic agent available for the treatment of Parkinson disease. An understanding of the pharmacokinetics of any drug is crucial for the establishment of its optimal therapeutic regimen, but this assumes a special importance with levodopa (Nutt and Fellman, 1984). It is characterized by an extensive presystemic metabolism, a rapid absorption in the proximal small intestine and a very short plasma half-life due to its rapid metabolism. On the other hand, its efficacy is hampered as the disease advances by clinical response modifications, namely fluctuations and dyskinesias. Maintenance of constant plasma concentrations of levodopa largely abolishes the clinical fluctuations in Parkinsonian patients (Nutt, 1987; Contin et al., 1996). 
P. ovata husk could modify the absorption kinetics of levodopa, and consequently, its plasma concentrations. Fiber can retain a part of the dose administered or modify the gastric emptying as well as the absorption conditions in the small bowel or its presystemic clearance. Although clinical studies are necessary to determine the importance of drug interactions, it is advisable to carry out previous experimental trials, in particular when studying drugs employed in complicated pathologies, like levodopa, that also has a complex kinetics.

The aim of the present study is to provide initial data about the influence of $P$. ovata husk in the bioavailability and other pharmacokinetic parameters of levodopa. To carry out the study, levodopa was administered intravenously to establish its elimination kinetics and bioavailability, and by the oral route, with and without fiber, to determine the pharmacokinetic modifications caused.

\section{Experimental procedures}

\subsection{Study design}

Twenty four healthy New Zealand white rabbits weighing $2.42-3.35 \mathrm{~kg}$ were used. The animals were housed in individual metal cages, which allowed the isolation of faeces in a lower container to avoid coprophagia. The environmental conditions were: humidity $(55 \% \pm 10 \%)$, temperature $\left(19 \pm 2{ }^{\circ} \mathrm{C}\right)$ and $12 \mathrm{~h}$ light $-12 \mathrm{~h}$ dark cycle. Rabbits were maintained under these conditions at least 1 week before the assay, with free access to water and standard laboratory chow.

The rabbits were randomly divided into two groups (6 and 18 rabbits each one, respectively). All the animals of the first group received $20 \mathrm{mg} / \mathrm{kg}$ of levodopa (Sigma Chemical Co., St. Louis, MO) intravenously. Levodopa was administered as a solution in a mixture of saline: $0.1 \mathrm{~N} \mathrm{HCl}$ $(4: 1, \mathrm{v} / \mathrm{v})$ into the marginal ear vein.

On the other hand, the 18 rabbits of the second group were orally treated with $20 \mathrm{mg} / \mathrm{kg}$ of the levodopa solution. Twelve of them also received $P$. ovata husk (Plantaben ${ }^{\circledR}$, Madaus, Barcelona, Spain) immediately before levodopa administration at two different doses: $100 \mathrm{mg} / \mathrm{kg}$ (6 rabbits) and $400 \mathrm{mg} / \mathrm{kg}$ (6 rabbits).

Levodopa solution and fiber dispersed in water were administered by gastric intubation. A total of $50 \mathrm{ml}$ water was used for administration and cannula cleaning.

The rabbits were anaesthetized with sodium pentobarbital $(30 \mathrm{mg} / \mathrm{kg}$ body weight, i.v.) and the left carotid artery cannulated with a silicone catheter (Silastic Medical-grade tubing, $1.02 \mathrm{~mm}$ inner diameter $\times 2.16 \mathrm{~mm}$ outer diameter). Levodopa and fiber administration was carried out after total recovery from anaesthesia was achieved.

Blood samples $(3 \mathrm{ml})$ were obtained from the left carotid artery through the cannula into heparinized containers, before and at $3,5,10,20,30,60,90,120,150,180,210$,
240, 270 and 300 min after levodopa intravenous administration and before and at 5, 10, 20,30,60, 90, 120, 150, $180,210,240,270$ and $300 \mathrm{~min}$ after levodopa oral administration, with and without fiber. Immediately after collection, plasma was separated by centrifugation and stored at $-20{ }^{\circ} \mathrm{C}$ until analyzed.

Levodopa extraction from plasma samples was carried out by using a catecholamine kit (Chromsystems ${ }^{\circledR}$ ) and was quantitated by HPLC with electrochemical detection. Neither heparin nor pentobarbital interfered on the assay.

\subsection{Pharmacokinetic studies}

Pharmacokinetic analysis was performed based on a compartmental (intravenous route) as well as on noncompartmental (intravenous and oral routes) description of the data observed.

For compartmental analysis, plasma levodopa concentration-time profiles were individually fitted to the following exponential equation:

$C_{\mathrm{p}}=\sum_{i=1}^{n} C_{\mathrm{i}} e^{-\lambda t}$

where $C_{\mathrm{i}}$ is the $y$-intercept, $\lambda$ is the slope of each of $n$ firstorder rate processes, $e$ is the exponential function (base $e$ ) and $t$ is time.

The pharmacokinetic model best describing the plasma data concentration-time courses of levodopa administered by intravenous route was determined using the WinNonlin computer program (Pharsight, Mountain View, CA). The equations were fitted to the data using a weighting factor

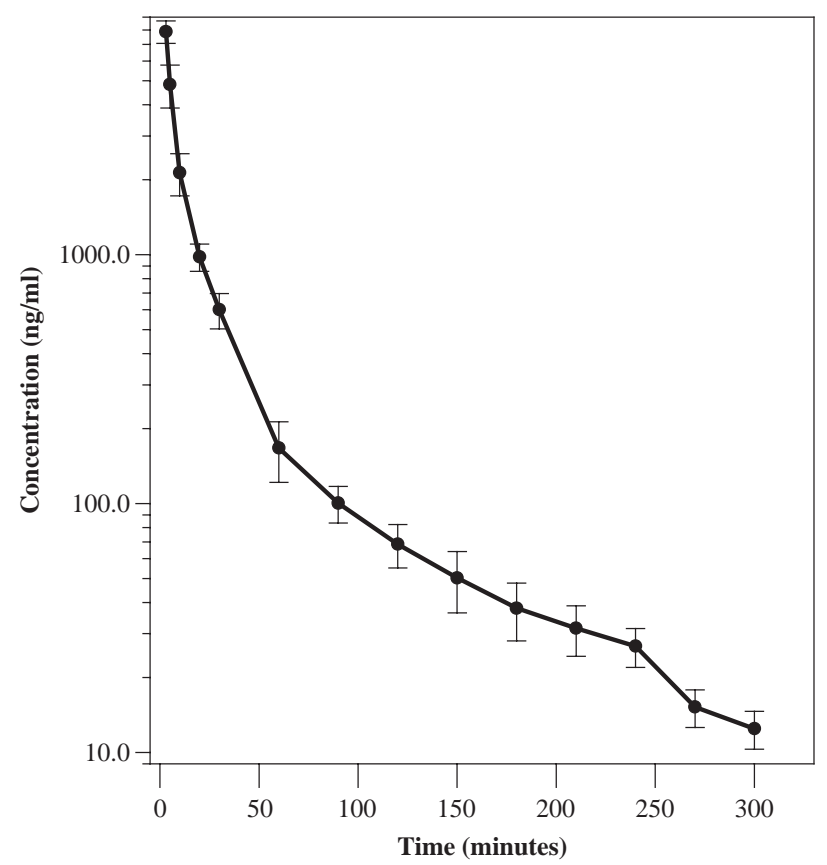

Fig. 1. Mean plasma concentrations of levodopa in rabbits after intravenous administration of $20 \mathrm{mg} / \mathrm{kg}$. 
Table 1

Pharmacokinetic parameters obtained by compartmental analysis in rabbits after intravenous administration of $20 \mathrm{mg} / \mathrm{kg}$ levodopa

\begin{tabular}{|c|c|c|c|c|c|c|c|c|}
\hline \multirow[t]{2}{*}{ Parameters } & \multicolumn{6}{|l|}{ Animal } & \multirow[t]{2}{*}{$\bar{X} \pm s$} & \multirow[t]{2}{*}{$\mathrm{CV}(\%)$} \\
\hline & 1 & 2 & 3 & 4 & 5 & 6 & & \\
\hline$A(\mathrm{ng} / \mathrm{ml})$ & 5416 & 8177 & 5973 & 7396 & 7874 & 7101 & $6989 \pm 1084$ & 15.52 \\
\hline$B(\mathrm{ng} / \mathrm{ml})$ & 183 & 248 & 364 & 221 & 255 & 201 & $245 \pm 64.5$ & 26.30 \\
\hline$C_{0}(\mathrm{ng} / \mathrm{ml})$ & 5599 & 8425 & 6337 & 7617 & 8129 & 7302 & $7235 \pm 1082$ & 14.95 \\
\hline$\alpha\left(\min ^{-1}\right)$ & 0.1023 & 0.1282 & 0.0994 & 0.1007 & 0.1017 & 0.0997 & $0.1053 \pm 0.0113$ & 10.70 \\
\hline$\beta\left(\min ^{-1}\right)$ & 0.0090 & 0.0105 & 0.0106 & 0.0098 & 0.0101 & 0.0102 & $0.0100 \pm 0.0006$ & 5.86 \\
\hline $\mathrm{AUC}\left(\mu \mathrm{g} \min \mathrm{ml}^{-1}\right)$ & 73.3 & 87.5 & 94.5 & 95.9 & 103 & 90.8 & $90.8 \pm 9.97$ & 10.98 \\
\hline$k_{10}\left(\min ^{-1}\right)$ & 0.0764 & 0.0963 & 0.0670 & 0.0794 & 0.0792 & 0.0804 & $0.0798 \pm 0.0095$ & 11.88 \\
\hline$k_{12}\left(\min ^{-1}\right)$ & 0.0229 & 0.0284 & 0.0273 & 0.0187 & 0.0196 & 0.0168 & $0.0223 \pm 0.0048$ & 21.35 \\
\hline$k_{21}\left(\min ^{-1}\right)$ & 0.0120 & 0.0139 & 0.0157 & 0.0124 & 0.0130 & 0.0127 & $0.0133 \pm 0.0013$ & 10.06 \\
\hline$t_{1 / 2 \alpha}(\min )$ & 6.77 & 5.41 & 6.97 & 6.89 & 6.81 & 6.95 & $6.63 \pm 0.61$ & 9.15 \\
\hline$t_{1 / 2 \beta}(\min )$ & 77.3 & 66.2 & 65.6 & 70.6 & 68.7 & 67.7 & $69.3 \pm 4.31$ & 6.22 \\
\hline$t_{1 / 2 k 10}(\min )$ & 9.08 & 7.20 & 10.3 & 8.73 & 8.75 & 8.62 & $8.79 \pm 1.01$ & 11.45 \\
\hline$V_{\mathrm{c}}\left(1 \mathrm{~kg}^{-1}\right)$ & 3.57 & 2.37 & 3.16 & 2.63 & 2.46 & 2.74 & $2.82 \pm 0.46$ & 16.25 \\
\hline$V_{\mathrm{p}}\left(1 \mathrm{~kg}^{-1}\right)$ & 6.82 & 4.85 & 5.49 & 3.94 & 3.73 & 3.63 & $4.74 \pm 1.25$ & 26.36 \\
\hline$V_{\mathrm{ss}}\left(1 \mathrm{~kg}^{-1}\right)$ & 10.4 & 7.22 & 8.64 & 6.56 & 6.19 & 6.37 & $7.56 \pm 1.65$ & 21.82 \\
\hline$V_{\mathrm{a}}\left(1 \mathrm{~kg}^{-1}\right)$ & 30.4 & 21.9 & 20.0 & 21.2 & 19.3 & 21.5 & $22.4 \pm 4.06$ & 18.14 \\
\hline $\mathrm{Cl}\left(\mathrm{ml} \mathrm{k}^{-1} \min ^{-1}\right)$ & 273 & 229 & 212 & 208 & 195 & 220 & $223 \pm 27.1$ & 12.15 \\
\hline
\end{tabular}

$\left(1 / C^{2}\right)$, and the optimum number of first-order rate processes was determined by Akaike criterion and residual analysis. Other compartmental parameters were calculated by standard methods (Gibaldi and Perrier, 1982).

The WinNonlin computer program and formulae described by Gibaldi and Perrier (1982) were also used to calculate the model-independent pharmacokinetic parameters. Maximum plasma levodopa concentration $\left(C_{\max }\right)$ and the time to reach maximum concentration $\left(t_{\max }\right)$ were read directly from the individual plasma concentration-time curves.

\subsection{Statistical evaluation}

All pharmacokinetic parameters were calculated for each animal and the data presented as arithmetic mean \pm standard deviation (mean $\pm \mathrm{SD}$ ). Data were analyzed by analyses of variance (ANOVA) and the Duncan's test was used to evaluate differences between data sets. When the data were not normal or there was not uniformity in the variance, Kruskal-Wallis test was used, and when the results were significant, Wilcoxon test with Bonferroni correction was used to assess differences between data sets. Differences between compartmental and non-compartmental data were determined by the $t$-test. $P \leq 0.05$ was used as the level of significance for all analyses.

\section{Results}

\subsection{Intravenous route}

Mean plasma concentrations of levodopa as a function of time following the administration of $20 \mathrm{mg} / \mathrm{kg}$ to rabbits are shown in Fig. 1.

After compartmental analysis, the plasma concentrationtime curves were best resolved in all experiments into a twocompartment open model.

The pharmacokinetic parameters derived from compartmental analysis are summarized in Table 1, and those calculated by non-compartmental analysis in Table 2 .

The mean values of $k_{12} / k_{21}, V_{\mathrm{c}} / V_{\mathrm{p}}$ and $k_{12} / k_{13}$ show that levodopa was widely distributed within the rabbit, with extensive and ready access to the peripheral compartment and a higher tendency to eliminate than to distribute.

Table 2

Pharmacokinetic parameters obtained by non-compartmental analysis in rabbits after intravenous administration of $20 \mathrm{mg} / \mathrm{kg}$ levodopa

\begin{tabular}{|c|c|c|c|c|c|c|c|c|}
\hline \multirow[t]{2}{*}{ Parameters } & \multicolumn{6}{|l|}{ Animal } & \multirow[t]{2}{*}{$\bar{X} \pm s$} & \multirow[t]{2}{*}{ CV $(\%)$} \\
\hline & 1 & 2 & 3 & 4 & 5 & 6 & & \\
\hline$\lambda\left(\min ^{-1}\right)$ & 0.0110 & 0.0105 & 0.0108 & 0.0098 & 0.0090 & 0.0101 & $0.0102 \pm 0.0007$ & 7.20 \\
\hline $\operatorname{AUC}\left(\mu \mathrm{g} \min \mathrm{ml}^{-1}\right)^{\mathrm{a}}$ & 100 & 105 & 135 & 119 & 116 & 127 & $117 \pm 13.1$ & 11.24 \\
\hline $\mathrm{Cl}\left(\mathrm{ml} \mathrm{kg}^{-1} \min ^{-1}\right)^{\mathrm{a}}$ & 200 & 191 & 148 & 167 & 173 & 158 & $173 \pm 19.6$ & 11.35 \\
\hline$V_{\mathrm{a}}\left(1 \mathrm{~kg}^{-1}\right)^{\mathrm{a}}$ & 18.2 & 18.2 & 13.8 & 17.1 & 19.3 & 15.7 & $17.0 \pm 2.02$ & 11.88 \\
\hline$V_{\mathrm{ss}}\left(1 \mathrm{~kg}^{-1}\right)^{\mathrm{a}}$ & 5.25 & 5.22 & 4.36 & 4.35 & 5.37 & 3.44 & $4.66 \pm 0.75$ & 16.11 \\
\hline$t_{1 / 2 \lambda}(\min )$ & 63.1 & 66.1 & 64.3 & 70.7 & 77.3 & 68.9 & $68.4 \pm 5.20$ & 7.60 \\
\hline $\operatorname{AUMC}\left(\mu \mathrm{g} \min ^{2} \mathrm{ml}^{-1}\right)$ & 2628 & 2860 & 3967 & 3102 & 3583 & 2771 & $3152 \pm 521$ & 16.53 \\
\hline MRT (min) & 26.3 & 27.3 & 29.4 & 26.0 & 31.0 & 21.9 & $27.0 \pm 3.17$ & 11.74 \\
\hline
\end{tabular}

${ }^{\text {a }}$ Significant differences with compartmental parameter $(t$-test, $P \leq 0.05)$. 


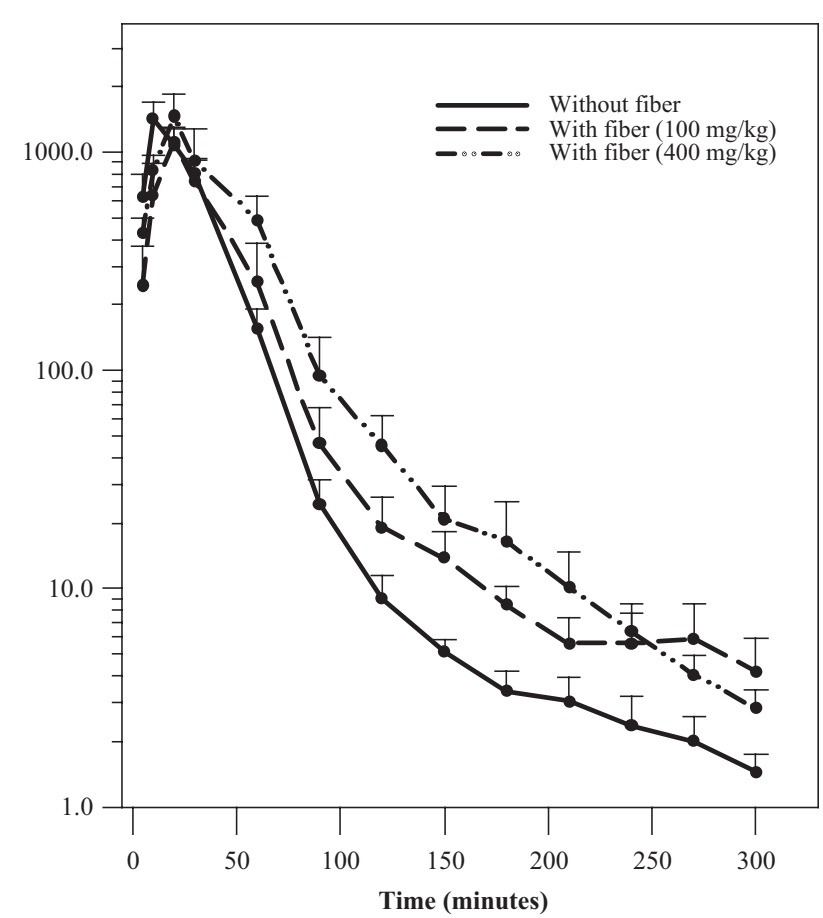

Fig. 2. Mean plasma concentrations of levodopa in rabbits after oral administration of $20 \mathrm{mg} / \mathrm{kg}$ alone and in the presence of fiber (100 or 400 $\mathrm{mg} / \mathrm{kg})$.

There were not significant differences between the data obtained using the compartmental and non-compartmental analysis when $\lambda / \beta$ and $t_{1 / 2 \lambda} / t_{1 / 2 \beta}$ values were compared, while AUC, $V_{\mathrm{a}}, V_{\mathrm{ss}}$ and $\mathrm{Cl}$ showed significant changes.

\subsection{Oral route}

The plot of mean plasma levodopa concentrations as a function of time after oral administration for the three groups studied are shown in Fig. 2 (levodopa alone and in the presence of 100 and $400 \mathrm{mg} / \mathrm{kg}$ of $P$. ovata husk).

The non-compartmental pharmacokinetic parameters obtained after the administration of levodopa alone and in the presence of 100 and $400 \mathrm{mg} / \mathrm{kg}$ of $P$. ovata husk are summarized in Tables 3, 4, and 5. We have not included the results obtained after compartmental analysis because the plasma concentration-time data were not adequately fitted to the classical compartmental open models (one, two and three compartments) tested.

After non-compartmental analysis, the mean AUC values calculated were slightly lower when $P$. ovata husk was administered at the dose of $100 \mathrm{mg} / \mathrm{kg}\left(43.4 \pm 11.6 \mu \mathrm{g} \mathrm{min} \mathrm{ml}^{-1}\right)$ than when levodopa was administered without fiber $\left(47.1 \pm 6.25 \mu \mathrm{g} \mathrm{min} \mathrm{ml}^{-1}\right)$. However, when the fiber was administered at the dose of $400 \mathrm{mg} / \mathrm{kg}$, mean AUC value was higher than in the other two groups $\left(62.2 \pm 17.2 \mu \mathrm{g} \mathrm{min} \mathrm{ml}^{-1}\right)$ (no significant differences).

When comparing the value of AUC obtained after levodopa oral administration with that found after intravenous administration, it can be seen that the fraction of dose absorbed is $40.3 \%$ when levodopa is administered alone; $37.2 \%$ when $100 \mathrm{mg} / \mathrm{kg}$ of $P$. ovata husk are given, and $53.2 \%$ when the dose of fiber is $400 \mathrm{mg} / \mathrm{kg}$. The low percentage of absorption reflects the presystemic metabolism of levodopa, that diminishes when increasing the dose of $P$. ovata husk.

An important fact is that the amount of levodopa available from $60 \mathrm{~min}$ on after its administration in the presence of fiber $(100 \mathrm{mg} / \mathrm{kg})$ was two times higher than when it was administered alone. On the other hand, when $P$. ovata husk was administered at the dose of $400 \mathrm{mg} / \mathrm{kg}$, the amount of drug available from $20 \mathrm{~min}$ on after administration increased $67 \%$.

The value of $C_{\max }$ obtained in the control group $\left(1.43 \pm 0.28 \mu \mathrm{g} \mathrm{ml}^{-1}\right)$ was higher than in the $100 \mathrm{mg} / \mathrm{kg}$ Plantago group $\left(1.04 \pm 0.30 \mu \mathrm{g} \mathrm{ml}^{-1}\right)$ and similar as in the $400 \mathrm{mg} / \mathrm{kg}$ Plantago group $\left(1.46 \pm 0.39 \mu \mathrm{g} \mathrm{m}{ }^{-1}\right)$. No significant differences were found for this parameter among the three groups. In relation to $t_{\max }$, the values obtained indicate that levodopa absorption is faster when the drug is administered alone $(10 \mathrm{~min})$ than when the fiber is given (20 min in both groups).

Levodopa mean residence time (MRT) is higher when this drug is administered with fiber. The values obtained for this parameter were: $29.7 \mathrm{~min}$ when levodopa is administered alone; $49.5 \mathrm{~min}$ with $100 \mathrm{mg} / \mathrm{kg}$ of fiber and $42.9 \mathrm{~min}$ with $400 \mathrm{mg} / \mathrm{kg}$ of fiber, being the differences significant.

Table 3

Pharmacokinetic parameters obtained by non-compartmental analysis in rabbits after oral administration of $20 \mathrm{mg} / \mathrm{kg}$ levodopa

\begin{tabular}{|c|c|c|c|c|c|c|c|c|}
\hline \multirow[t]{2}{*}{ Parameters } & \multicolumn{6}{|l|}{ Animal } & \multirow[t]{2}{*}{$\bar{X} \pm s$} & \multirow[t]{2}{*}{$\mathrm{CV}(\%)$} \\
\hline & 1 & 2 & 3 & 4 & 5 & 6 & & \\
\hline$\lambda\left(\min ^{-1}\right)$ & 0.0086 & 0.0075 & 0.0070 & 0.0069 & 0.0069 & 0.0062 & $0.0072 \pm 0.0008$ & 11.26 \\
\hline $\operatorname{AUC}\left(\mu \mathrm{g} \min \mathrm{ml}^{-1}\right)$ & 56.1 & 42.9 & 53.4 & 46.5 & 42.9 & 40.8 & $47.1 \pm 6.25$ & 13.28 \\
\hline$C_{\max }\left(\mu \mathrm{g} \mathrm{ml} \mathrm{m}^{-1}\right)$ & 1.67 & 1.26 & 1.82 & 1.47 & 1.24 & 1.09 & $1.43 \pm 0.280$ & 19.70 \\
\hline$t_{\max }(\min )$ & 10.0 & 10.0 & 10.0 & 10.0 & 10.0 & 10.0 & $10.0 \pm 0.00$ & 0.00 \\
\hline $\mathrm{Cl} / F\left(\mathrm{ml} \mathrm{kg}^{-1} \min ^{-1}\right)$ & 357 & 466 & 375 & 430 & 466 & 490 & $425 \pm 54.2$ & 12.76 \\
\hline$V_{\mathrm{a}} / F\left(1 \mathrm{~kg}^{-1}\right)$ & 41.5 & 62.2 & 53.6 & 62.3 & 67.6 & 79.1 & $59.1 \pm 12.7$ & 21.52 \\
\hline$V_{\mathrm{ss}} / F\left(1 \mathrm{~kg}^{-1}\right)$ & 10.4 & 14.0 & 10.6 & 11.5 & 14.5 & 16.9 & $12.9 \pm 2.52$ & 19.59 \\
\hline$t_{1 / 2 \lambda}(\min )$ & 80.6 & 92.4 & 99.0 & 100 & 100 & 111 & $96.5 \pm 10.4$ & 10.73 \\
\hline $\operatorname{AUMC}\left(\mu \mathrm{g} \min ^{2} \mathrm{ml}^{-1}\right)$ & 1633 & 1222 & 1513 & 1245 & 1333 & 1403 & $1391 \pm 159$ & 11.45 \\
\hline MRT (min) & 29.1 & 28.5 & 28.4 & 26.8 & 31.1 & 34.4 & $29.7 \pm 2.68$ & 9.03 \\
\hline$F(\%)$ & & & & & & & 40.3 & \\
\hline
\end{tabular}


Table 4

Pharmacokinetic parameters obtained by non-compartmental analysis in rabbits after oral administration of $20 \mathrm{mg} / \mathrm{kg}$ levodopa in the presence of fiber $(100 \mathrm{mg} / \mathrm{kg})$

\begin{tabular}{|c|c|c|c|c|c|c|c|c|}
\hline \multirow[t]{2}{*}{ Parameters } & \multicolumn{6}{|l|}{ Animal } & \multirow[t]{2}{*}{$\bar{X} \pm s$} & \multirow[t]{2}{*}{$\mathrm{CV}(\%)$} \\
\hline & 1 & 2 & 3 & 4 & 5 & 6 & & \\
\hline$\lambda\left(\min ^{-1}\right)$ & 0.0051 & 0.0053 & 0.0045 & 0.0058 & 0.0056 & 0.0080 & $0.0057 \pm 0.0012$ & 21.09 \\
\hline $\operatorname{AUC}\left(\mu \mathrm{g} \min \mathrm{ml}^{-1}\right)$ & 54.7 & 41.5 & 29.7 & 46.9 & 56.9 & 30.9 & $43.4 \pm 11.6$ & 26.63 \\
\hline$C_{\max }\left(\mu \mathrm{g} \mathrm{ml}^{-1}\right)$ & 1.38 & 0.938 & 0.560 & 1.33 & 1.11 & 0.925 & $1.04 \pm 0.304$ & 29.18 \\
\hline$t_{\max }(\min )$ & 20.0 & 20.0 & 20.0 & 20.0 & 20.0 & 20.0 & $20.0 \pm 0.00$ & 0.00 \\
\hline $\mathrm{Cl} / F\left(\mathrm{ml} \mathrm{kg}^{-1} \min ^{-1}\right)$ & 366 & 482 & 673 & 426 & 351 & 647 & $491 \pm 139$ & 28.36 \\
\hline$V_{\mathrm{a}} / F\left(1 \mathrm{~kg}^{-1}\right)$ & 71.8 & 90.9 & 150 & 73.5 & 62.7 & 80.9 & $88.2 \pm 31.5$ & 35.70 \\
\hline$V_{\mathrm{ss}} / F\left(1 \mathrm{~kg}^{-1}\right)$ & 11.6 & 15.4 & 43.5 & 25.8 & 11.4 & 49.3 & $26.2 \pm 16.6$ & 63.57 \\
\hline$t_{1 / 2 \lambda}(\min )$ & 135.88 & 130.75 & 154.00 & 119.48 & 123.75 & 86.63 & $125.08 \pm 22.3479$ & 17.87 \\
\hline $\operatorname{AUMC}\left(\mu \mathrm{g} \min ^{2} \mathrm{ml}^{-1}\right)$ & 1732 & 1328 & 1919 & 2833 & 1845 & 2355 & $2002 \pm 524$ & 26.19 \\
\hline MRT (min) & 31.7 & 32.0 & 64.6 & 60.4 & 32.4 & 76.2 & $49.5 \pm 19.9$ & 40.13 \\
\hline$F(\%)$ & & & & & & & 37.2 & \\
\hline
\end{tabular}

The differences observed in $\mathrm{Cl} / F, V_{\mathrm{a}} / F$ and $V_{\mathrm{ss}} / F$ values can be attributed to variations in the fraction of levodopa absorbed $(F)$.

\section{Discussion}

As in this study, the two-compartment open model was used by other authors to describe levodopa intravenous pharmacokinetics in rats (Rose et al., 1991), in beagle dogs (Deleu et al., 1991), in rhesus monkeys (Hammerstad et al., 1990) and in man (Gancher et al., 1987) when this drug was administered alone or in combination with a peripheral inhibitor of the aromatic aminoacid decarboxylase (AADC) like carbidopa.

After levodopa oral administration, the pharmacokinetic studies carried out are generally non-compartmental (Rabey et al., 1991; Contin et al., 1996; Murata and Kazanawa, 1997), perhaps due to the marked fluctuations in plasma concentrations caused by the peculiar characteristics of levodopa.

Following oral administration, approximately $40 \%$ of levodopa dose reaches the systemic circulation, and this data is in agreement with those reported by other authors (Andersson et al., 1975; Contin et al., 1996).

Regarding $t_{\max }$, the values obtained when levodopa was administered alone (10 $\mathrm{min}$ ) and in the presence of fiber (20 min) were similar to the reported by Deleu et al. (1991) in dogs and lower than those reported by several authors in men, which ranged from $30 \mathrm{~min}$ to $2 \mathrm{~h}$ (Bredberg et al., 1990; Contin et al., 1993).

Data obtained for the plasma elimination half-lives of levodopa when was intravenously $(68.4 \mathrm{~min})$ or orally administered $(96.5 \mathrm{~min}$ ) are longer than those reported in rats by Sasahara et al. (1980) after intravenous bolus injections (39 $\mathrm{min}$ ) and by Grange et al. (2001) after oral administration (24 min).

Pharmacokinetic drug interactions have been the subject of numerous studies, but few of them have been carried out with dietary fiber, being the results obtained variable. We have not found any study about the interaction between levodopa and hydrosoluble fiber, and only one carried out with an insoluble fiber. Astarloa et al. (1992) found that a high-insoluble fiber (bran of wheat and pectin) diet caused a $71 \%$ increase in levodopa bioavailability via an increase in

Table 5

Pharmacokinetic parameters obtained by non-compartmental analysis in rabbits after oral administration of $20 \mathrm{mg} / \mathrm{kg}$ levodopa in the presence of fiber $(400 \mathrm{mg} / \mathrm{kg})$

\begin{tabular}{|c|c|c|c|c|c|c|c|c|}
\hline \multirow[t]{2}{*}{ Parameters } & \multicolumn{6}{|l|}{ Animal } & \multirow[t]{2}{*}{$\bar{X} \pm s$} & \multirow[t]{2}{*}{ CV $(\%)$} \\
\hline & 1 & 2 & 3 & 4 & 5 & 6 & & \\
\hline$\lambda\left(\min ^{-1}\right)^{\mathrm{a}, \mathrm{b}, \mathrm{c}}$ & 0.0132 & 0.0164 & 0.0097 & 0.0157 & 0.0078 & 0.0171 & $0.0133 \pm 0.0038$ & 28.70 \\
\hline $\mathrm{AUC}\left(\mu \mathrm{g} \min \mathrm{ml}^{-1}\right)$ & 61.6 & 48.5 & 91.2 & 61.2 & 68.6 & 41.9 & $62.2 \pm 17.2$ & 27.72 \\
\hline$C_{\max }\left(\mu \mathrm{g} \mathrm{ml}^{-1}\right)$ & 1.53 & 1.23 & 1.98 & 1.48 & 1.72 & 0.861 & $1.46 \pm 0.388$ & 26.47 \\
\hline$t_{\max }(\min )$ & 20.0 & 20.0 & 20.0 & 20.0 & 20.0 & 20.0 & $20.0 \pm 0.00$ & 0.00 \\
\hline $\mathrm{Cl} / F\left(\mathrm{ml} \mathrm{kg}^{-1} \min ^{-1}\right)$ & 325 & 412 & 219 & 327 & 291 & 477 & $342 \pm 91.0$ & 26.60 \\
\hline$V_{\mathrm{a}} / F\left(1 \mathrm{~kg}^{-1}\right)^{\mathrm{b}, \mathrm{c}}$ & 24.6 & 25.1 & 22.6 & 20.8 & 37.4 & 27.9 & $26.4 \pm 5.88$ & 22.26 \\
\hline$V_{\mathrm{ss}} / F\left(1 \mathrm{~kg}^{-1}\right)$ & 13.1 & 18.1 & 9.46 & 13.8 & 11.3 & 23.4 & $14.9 \pm 5.08$ & 34.22 \\
\hline$t_{1 / 2 \lambda}(\min )^{\mathrm{d}, \mathrm{e}, \mathrm{f}}$ & 52.5 & 42.3 & 71.4 & 44.1 & 88.9 & 40.5 & $56.6 \pm 19.5$ & 34.40 \\
\hline $\operatorname{AUMC}\left(\mu \mathrm{g} \min ^{2} \mathrm{ml}^{-1}\right)^{\mathrm{a}, \mathrm{b}}$ & 2477 & 2131 & 3935 & 2590 & 2658 & 2052 & $2641 \pm 680$ & 25.75 \\
\hline MRT (min) $)^{\mathrm{a}, \mathrm{b}}$ & 40.2 & 43.9 & 43.1 & 42.3 & 38.7 & 49.0 & $42.9 \pm 3.54$ & 8.26 \\
\hline$F(\%)$ & & & & & & & 53.2 & \\
\hline
\end{tabular}

Significant differences between levodopa and levodopa + fiber $(100 \mathrm{mg} / \mathrm{kg})$ groups: ${ }^{\mathrm{a}}$ Wilcoxon modified test, ${ }^{\mathrm{d}}$ Duncan test, $P=0.05$. Significant differences between levodopa and levodopa + fiber $(400 \mathrm{mg} / \mathrm{kg})$ groups: ${ }^{\mathrm{b}}$ Wilcoxon modified test, ${ }^{\mathrm{e}}$ Duncan test, $P=0.05$. Significant differences between levodopa + fiber $(100 \mathrm{mg} / \mathrm{kg})$ and levodopa + fiber $(400 \mathrm{mg} / \mathrm{kg})$ groups: ${ }^{\mathrm{c}}$ Wilcoxon modified test, ${ }^{\mathrm{f}}$ Duncan test, $P=0.05$. 
gastrointestinal motility in patients with Parkinson's disease who also had severe constipation.

In relation to the interactions between $P$. ovata husk and other drugs, it has been shown that it causes a reduction in the absorption of lithium salts (Perlman, 1990) and delays that of ethinylestradiol (García et al., 2000). Data obtained by Liel et al. (1996) and Chiu and Sherman (1998) are contradictory. Thus, after the consumption of $P$. ovata husk and levothyroxine, Liel et al. (1996) found a reduction in the extent of drug absorbed, but Chiu and Sherman (1998) could not demonstrate this interaction. When this fiber was taken with carbamazepine, it was probed that there was a decrease in the absorption of this drug (Etman, 1995), but other authors did not found any interference in the absorption process (Ettinger et al., 1992).

One of the possible mechanisms that would explain the interaction between fiber and drugs is a modification in the gastric emptying. This mechanism would be important for levodopa due to the stomach has a very limited capacity to absorb this drug, but can decarboxylate it (Rivera-Calimlim et al., 1970).

Several soluble dietary fibers as guar gum or pectin have been shown to delay the gastric emptying of liquids and solids, probably due to an increase in meal viscosity (Russell and Bass, 1985). Nevertheless, other authors did not find this action: Bianchi and Capurso (2002) demonstrated that the addition of different dietary fibers (guar gum and ispaghula) to a solid meal did not influence gastric emptying. Frost et al. (2003) probed that psyllium-enriched pasta had no significant effect on gastric emptying and Rigaud et al. (1998) concluded that psyllium did not slow down the gastric emptying of hydrosoluble nutrients, but increased the time allowed for intestinal absorption.

Some changes in the pharmacokinetic parameters of levodopa after its administration with $P$. ovata husk could be due to a delay in the gastric emptying of the drug that would lead to a greater degradation of levodopa in the stomach, delaying $t_{\max }$ and explaining the modification in the curves shape. However, and in agreement with Fernández et al. (1998), García et al. (2000) and Rigaud et al. (1998), we think that these changes principally occur because the fiber forms a highly viscous solution, trapping levodopa inside it, and therefore, there is a decrease in drug absorption in the intestine and consequently lower values for $C_{\max }$ are obtained.

On the other hand, we have observed that levodopa concentrations are always higher since certain time on (depending on the group studied) in the presence of fiber and the extent of levodopa absorbed increases with the dose of fiber administered. Another mechanism, different from those previously pointed out, as a modification in the presystemic metabolism of levodopa, should participate in this $P$. ovata husk action.

Following oral administration, levodopa is highly metabolized to dopamine by the enzyme aromatic aminoacid decarboxylase (AADC) in the gut (Andersson et al., 1975).
P. ovata husk, or the products derived from its partial hydrolysis in the stomach could diminish its presystemic metabolism since certain time on, resulting in higher concentrations of levodopa since that moment.

It has been probed that dietary fiber, and hydrosoluble fiber in particular, can modify the intestinal enzymatic activity, both the gut wall enzymes (Leng-Peschlow, 1991) as well as those of the intestinal content (Isaksson et al., 1982; Leng-Peschlow, 1991). Results obtained by several authors regarding $P$. ovata husk on the enzyme activity are contradictory. Leng-Peschlow (1989) concluded that this fiber had no effect (pepsin, trypsin, alpha-amilase) or a stimulating action (chymotrypsin, lipase, lactase). Nevertheless, Isaksson et al. (1982) found that P. ovata husk affected the lipase activity, which was moderately inhibited; Hansen (1986) established that this fiber led to an inhibition of the activity of proteolytic pancreatic enzymes in vitro and Leng-Peschlow (1991) indicated that it reduced $\beta$-glucuronidase activity in rats.

On the other hand, Hansen (1986) indicated that the fiber effect on proteolytic enzyme activity was proportional to fiber concentration and inversely related to enzyme level. Our results are in agreement with these observations: the extent of levodopa absorbed is higher with the higher dose of fiber administered (100 versus $400 \mathrm{mg} / \mathrm{kg}$ ).

Finally, another aspect that could have contributed to the results obtained with the fiber could be an increase in the paracelullar absorption of levodopa across the gut wall, avoiding its possible degradation by the enzymes located inside the cells of the gut wall.

The presence of fiber could increase the paracellular transport of levodopa, which would contribute to a higher absorption of the unaltered drug. Lennernäs et al. (1993) proposed that levodopa, small and hydrophilic molecule, can be absorbed by the paracellular route. However, further studies (Nilsson et al., 1994) concluded that the variability in the absorption of levodopa in Parkinson's disease cannot be explained by differences in transmucosal water flux in the human small intestine.

In conclusion, and although further studies administering levodopa with an AADC inhibitor like carbidopa are necessary, as well as the clarification of levodopa/fiber interaction mechanism, we think that $P$. ovata husk offers interesting perspectives to be administered to patients with Parkinson disease. This fiber would be useful in those patients who suffer constipation, but also would be beneficial in every patient with Parkinson due to the favourable modification it causes in levodopa pharmacokinetics.

In this way, fiber administration can reduce severity of dopamine mediated gastrointestinal and cardiovascular adverse effects by providing lower levodopa maximum concentrations and also provide a more uniform response by maintaining plasma concentrations in a narrower range. Several authors have indicated that the induction of on/off phenomena and dyskinesias may be the result of an active process of adaptation to variations in brain and plasma 
levodopa levels. In this way, when levodopa concentrations are maintained at a constant level by intravenous infusion dyskinesias and fluctuations are greatly reduced (Mouradian et al., 1990; Chase et al., 1994). Finally, P. ovata husk can extend levodopa effect by increasing its half-life.

\section{Acknowledgement}

We wish to thank Madaus, S.A. Laboratory for its collaboration in this study.

\section{References}

Andersson, I., Granerus, A.K., Jagenburg, R., Svanborg, A., 1975. Intestinal decarboxylation of orally administered L-dopa: influence of pharmacological preparations, dose magnitude, dose sequence and food intake. Acta Med. Scand. 198, 415-420.

Astarloa, R., Mena, M.A., Sanchez, V., de la Vega, L., de Yebenes, J.G., 1992. Clinical and pharmacokinetic effects of a diet rich in insoluble fiber on Parkinson disease. Clin. Neuropharmacol. 15, 375-380.

Bianchi, M., Capurso, L., 2002. Effects of guar gum, ispaghula and microcrystalline cellulose on abdominal symptoms, gastric emptying, orocaecal transit time and gas production in healthy volunteers. Dig. Liver Dis. 34, S129-S133.

Bredberg, E., Tedroff, J., Aquilonius, S.M., Paalzow, L., 1990. Pharmacokinetics and effects of levodopa in advanced Parkinson's disease. Eur. J. Clin. Pharmacol. 39, 385-389.

Byrne, K.G., Pfeiffer, R.F., Quigley, E.M., 1994. Gastrointestinal dysfunction in Parkinson's disease: a report of clinical experience at a single center. J. Clin. Gastroenterol. 19, 11-16.

Chase, T.N., Engber, T.M., Mouradian, N.M., 1994. Palliative and prophylactic benefits of continuously administered dopaminomimetics in Parkinson's disease. Neurology 44, S15-S18.

Chiu, A.C., Sherman, S.I., 1998. Effects of pharmacological fiber supplements on levothyroxine absorption. Thyroid 8, 667-671.

Contin, M., Riva, R., Martinelli, P., Cortelli, P., Albani, F., Baruzzi, A., 1993. Pharmacodynamic modelling of oral levodopa: clinical application in Parkinson's disease. Neurology 43, 367-371.

Contin, M., Riva, R., Albani, F., Baruzzi, A., 1996. Pharmacokinetic optimisation in the treatment of Parkinson's disease. Clin. Pharmacokinet. 30, 463-481.

Deleu, D., Sarre, S., Ebinger, G., Michotte, Y., 1991. In vivo pharmacokinetics of levodopa and 3-O-methyldopa in muscle: a microdialysis study. Naunyn Schmiedeberg's Arch. Pharmacol. 344, 514-519.

Edwards, L.L., Quigley, E.M.M., Pfeiffer, R.F., 1992. Gastrointestinal dysfunction in Parkinson's disease: frequency and pathophysiology. Neurology 42, 726-732.

Etman, M.A., 1995. Effect of a bulk forming laxative on the bioavailability of carbamazepine in man. Drug Dev. Ind. Pharm. 21, 1901-1906.

Ettinger, A.B., Shinnar, S., Sinnett, M.J., Moshe, S.L., 1992. Carbamazepine-induced constipation. J. Epilepsy 5, 191-193.

Fernández, N., Diez, M.J., Terán, M.T., García, J.J., Calle, A.P., Sierra, M., 1998. Influence of two commercial fibers in the pharmacokinetics of ethinilestradiol in rabbits. J. Pharmacol. Exp. Ther. 286, 870-874.

Frost, G.S., Brynes, A.E., Dhillo, W.S., Bloom, S.R., McBurney, M.I., 2003. The effects of fiber enrichment of pasta and fat content on gastric emptying, GLP-1, glucose, and insulin responses to a meal. Eur. J. Clin. Nutr. 57, 293-298.

Gancher, S.T., Nutt, J.G., Woodward, W.R., 1987. Peripheral pharmacokinetics of levodopa in untreated, stable, and fluctuating Parkinsonian patients. Neurology 37, 940-944.
García, J.J., Fernández, N., Diez, M.J., Sahagún, A., González, A., Alonso, M.L., Prieto, C., Calle, A.P., Sierra, M., 2000. Influence of two dietary fibers in the oral bioavailability and other pharmacokinetic parameters of ethinyloestradiol. Contraception 62, 253-257.

Garnett, W.R., 1996. Gastrointestinal dysmotility and central nervous system disorders: use of cisapride in patients with Parkinson's disease. Consult. Pharm. 11, 10-16.

Gibaldi, M., Perrier, D., 1982. Multicompartment Models, 2nd ed. Pharmacokinetics. Marcel Dekker, New York.

Grange, S., Holford, N.H., Guentert, T.W., 2001. A pharmacokinetic model to predict the PK interaction of L-dopa and benserazide in rats. Pharm. Res. 18, 1174-1184.

Hammerstad, J.P., Woodward, W.R., Gliessman, P., Boucher, B., Nutt, J.G., 1990. L-dopa pharmacokinetics in plasma and cisternal and lumbar cerebrospinal fluid of monkeys. Ann. Neurol. 27, 495-499.

Hansen, W.E., 1986. Effect of dietary fiber on proteolytic pancreatic enzymes in vitro. Int. J. Pancreatol. 1, 341-351.

Isaksson, G., Lundquist, I., Ihse, I., 1982. Effect of dietary fiber on pancreatic enzyme activity in vitro. Gastroenterology 82, 918-924.

Leng-Peschlow, E., 1989. Interference of dietary fibres with gastrointestinal enzymes in vitro. Digestion 44, 200-210.

Leng-Peschlow, E., 1991. Plantago ovata seeds as dietary fibre supplement, physiological and metabolic effects in rats. Br. J. Nutr. 66, 331-349.

Lennernäs, H., Nilsson, D., Aquilonius, S.M., Ahrenstedt, O., Knutson, L., Paalzow, L.K., 1993. The effect of L-leucine on the absorption of levodopa, studied by regional jejunal perfusion in man. Br. J. Clin. Pharmacol. 35, 243-250.

Liel, Y., Harman-Boehm, I., Shany, S., 1996. Evidence for a clinically important adverse effect of fiber-enriched diet on the bioavailability of levothyroxine in adult hypothyroid patients. J. Clin. Endocrinol. Metab. $81,857-859$

Mouradian, M.M., Heuser, I.J., Baronti, F., Chase, T.N., 1990. Modification of central dopaminergic mechanisms by continuous levodopa therapy for advanced Parkinson's disease. Ann. Neurol. 27, 18-23.

Murata, M., Kanazawa, I., 1997. Effects of chronic levodopa therapy on dopa pharmacokinetics. Eur. Neurol. 38, 50-55.

Nilsson, D., Fagerholm, U., Lennernas, H., 1994. The influence of net water absorption on the permeability of antipyrine and levodopa in the human jejunum. Pharm. Res. 11, 1540-1547.

Nutt, J.G., 1987. On-off phenomenon: relation to levodopa pharmacokinetics and pharmacodynamics. Ann. Neurol. 22, 535-540.

Nutt, J.G., Fellman, J.H., 1984. Pharmacokinetics of levodopa. Clin. Neuropharmacol. 7, 35-49.

Perlman, B.B., 1990. Interaction between lithium salts and ispaghula husk. Lancet 17, 335.

Rabey, J.M., Schwartz, M., Graff, E., Harsat, A., Vered, Y., 1991. The influence of bromocriptine on the pharmacokinetics of levodopa in Parkinson's disease. Clin. Neuropharmacol. 14, 514-522.

Rigaud, D., Paycha, F., Meulemans, A., Merrouche, M., Mignon, M., 1998. Effect of psyllium on gastric emptying, hunger feeling and food intake in normal volunteers: a double blind study. Eur. J. Clin. Nutr. 52, 239-245.

Rivera-Calimlim, L., Dujovne, C.A., Morgan, J.P., Lasagna, L., Bianchine, J.R., 1970. L-dopa treatment failure: explanation and correction. Br. Med. J. 10, 93-94.

Rose, S., Jenner, P., Marsden, C.D., 1991. Peripheral pharmacokinetic handling and metabolism of L-dopa in the rat: the effect of route of administration and carbidopa pretreatment. J. Pharm. Pharmacol. 43, $325-330$

Russell, J., Bass, P., 1985. Canine gastric emptying of fiber meals: influence of meal viscosity and antroduodenal motility. Am. J. Physiol. 249, G662-G667.

Sasahara, K., Nitanai, T., Habara, T., Morioka, T., Nakajima, E., 1980. Dosage form design for improvement of bioavailability of levodopa II: bioavailability of marketed levodopa preparations in dogs and Parkinsonian patients. J. Pharm. Sci. 69, 261-265. 